Jurnal Kesehatan Perintis (Perintis's Health Journal) 7 (1) 2020: 22-31

Contents list available at JKP website

Jurnal Kesehatan Perintis (Perintis's Health Journal)

Journal homepage: https://jurnal.stikesperintis.ac.id/index.php/JKP

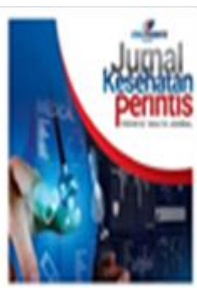

\title{
Uji Efektifitas Larutan Bawang Putih (Allium sativum) terhadap pertumbuhan Bakteri Staphylococcus Epidermidis
}

\author{
Sri Indrayati*, Pivin Eno Diana
}

\author{
Sekolah Tinggi Ilmu Kesehatan Perintis Padang, Sumatera Barat, Indonesia
}

Article Information :

Submission:Jun 2, 2020; Revised:Jun 30, 2020; Accepted:Jun 30, 2020; Available online: Jul 12, 2020

${ }^{*}$ Corresponding author : endlesofichy@gmail.com

\begin{abstract}
ABSTRAK
Bawang putih (Allium sativum) merupakan jenis tanaman umbi lapis yang memiliki nilai ekonomi yang sangat tinggi. Umumnya bawang putih dimanfaatkan sebagai bumbu dalam berbagai jenis masakan, selain itu bawang putih memiliki kandungan diallildisulfida (DADS) dan dialliltrisulfida (DATS) yang berperan sebagai anti bakteri. Acne vulgaris atau yang lebih dikenal dengan nama jerawat merupakan penyakit kulit obstruktif dan inflamatif yang disebabkan oleh bakteri Staphylococcus epidermidis. Tujuan dari penelitian ini untuk menguji daya hambat larutan bawang putih terhadap pertumbuhan bakteri $S$. epidermidis serta untuk mengetahui konsentrasi yang paling efektif dalam menghambat pertumbuhan bakteri Staphylococcus epidermidis. Hasil penelitian ini diharapkan dapat menjadi sumber informasi bagi masyarakat mengenai manfaat larutan bawang putih dalam menghambat pertumbuhan $S$. epidermidis sehingga dapat menjadi alternatif dalam pengobatan jerawat. Jenis penelitian ini adalah eksperimental dengan menggunakan metode disk diffusion. Penelitian ini dilakukan sebanyak enam kali pengulangan. Kontrol positif menggunakan antibiotic amoxicillin dan control negatifnya adalah aquadest steril sedangkan konsentrasi larutan bawang putih yang digunakan adalah 10\%, 40\%, 70\%, 100\%. Hasil penelitian menunjukkan bahwa larutan bawang putih memiliki daya hambat terhadap pertumbuhan bakteri S.epidermidis serta konsentrasi yang paling efektif dalam menghambat pertumbuhan bakteri $S$. epidermidis adalah pada konsentrasi $70 \%$. Hasil penelitian ini dapat menjadi acuan bahwa larutan bawang putih dapat dijadikan sebagai penghambat pertumbuhan Staphylococcus epidermidis sehingga dapat menjadi alternatif dalam pengobatan, salahsatunya dalam pengobatan jerawat.
\end{abstract}

Kata kunci : acne vulgaris, Bawang Putih (Allium sativum),Staphylococcus epidermidis, zona hambat

\section{ABSTRACT}

Garlic (Allium sativum) is a type of bulb which has a very high economic value. Can be used as a spice in various types of dishes, besides that garlic contains diallildisulfide (DADS) and dialliltrisulfida (DATS) which are used as an anti-bacterial. Acneovulgariso or better known by the name of acne is a skin disease that is obstructive and anti-inflammatory caused by the bacterium Staphylococcus epidermidis. The purpose of this study is to discuss the inhibitory power of garlic solution on the growth of $S$. epidermidis bacteria and to determine the most effective concentration in inhibiting the growth of Staphylococcus epidermidis bacteria. The results of this study are expected to be a source of information for the public regarding the use of garlic in overcoming the 
growth of S. epidermidis so that it can be an alternative in the treatment of acne. This type of research is experimental using the disk diffusion method. This research was conducted six times. The positive control using antibioticoamoxicillin and the negative control is aquadestosteril while the concentration of garlic capsules used is $10 \%, 40 \%, 70 \%, 100 \%$. The results showed that the white solution has inhibitory properties against the growth of S.epidermidis bacteria and also the most effective concentration in inhibiting the growth of $S$. epidermidis bacteria is at a concentration of $70 \%$. The results of this study can be a reference about white aid can be used as an inhibitor of the growth of Staphylococcus epidermidis so that it can be an alternative in treatment, one of which is in the treatment of acne.

Keywords : acne vulgaris, Garlic (Allium sativum), Staphylococcus epidermidis, inhibitory zone

\section{PENDAHULUAN}

Jerawat (acne vulgaris) merupakan suatu kondisi inflamasi pada bagian polisebaseus kulit yang ditandai dengan papul, pustul, komedo,dan nodul yang terjadi pada remaja dan dewasa muda (Afriyanti, 2015). Jerawat hampir dialami oleh hampir setiap orang. Jerawat biasanya dialami ketika memulai masa pubertas. Dari survey di kawasan Asia Tenggara terdapat 40$80 \%$ kasus akne vulgaris sedangkan menurut catatan studi dermatologi kosmetika Indonesia menunjukan yaitu $60 \%$ penderita akne vulgaris pada tahun 2006, $80 \%$ terjadi pada tahun 2007 dan 90\% pada tahun 2009. Prevelansi tertinggi yaitu pada umur 14-17 tahun, dimana pada wanita berkisar $83-85 \%$ dan pada pria yaitu pada umur 16-19 tahun berkisar 95-100\%. Pada umumnya banyak remaja yang bermasalah dengan akne vulgaris yang menimbulkan keresahan (Upa et al, 2017).

Meskipun akne vulgaris tidak mengancam kehidupan, namun dapat menyebabkan masalah serius dalam kondisi sosial dan psikologis penderita. (Zahrah, Mustika, \& Debora, 2018). Walaupun masalah jerawat ini tidak memberikan akibat yang fatal, tetapi cukup merisaukan karena bagi yang mengalaminya dapat menurunkan kepercayaan dirinya, terutama mereka yang peduli akan penampilan (Meilina \& Hasanah, 2018). Dari 317 responden yang memiliki masalah jerawat, 48,6\% diantaranya merasa stres, $19,4 \%$ takut untuk berfoto, $22 \%$ takut bertemu seseorang untuk pertama kali dan $8,5 \%$ takut untuk bertemu dengan teman (Vilar et al, 2015).

Penyebab jerawat meliputi hiperproliferasi epidermis folikular sehingga terjadi sumbatan folikel, produksi minyak berlebihan, inflamasi, dan aktivitas bakteri. Bakteri yang dapat memicu tumbuhnya jerawat diantaranya adalah $P$. acnes dan $S$. epidermidis (Wahdaningsih, Untari, \& Fauziah, 2014).

Bakteri S. epidermis ini secara alami hidup di membran kulit dan membran mukosa manusia. Bakteri $S$. epidermidis umumnya telah resisten terhadap antibiotik penisilin dan metisilin. Penggunaan metisilin menyebabkan resistensi terhadap antibiotik lain seperti rifamisin, gentamisin, tetrasiklin, kloramfenikol, eritromisin, clindamisin, dan sulfonamid. Pemberian antibiotik yang berlebihan akan menyebabkan bakteri patogen menjadi resisten, selain itu obat-obatan jenis antibiotik relatif lebih mahal (Mei, 2016).

Faktor utama penyebab semakin kebalnya suatu bakteri terhadap antibiotik yaitu karena penggunaan antibiotik itu sendiri. Munculnya kuman-kuman patogen yang kebal terhadap satu (antimicrobacterial resistance) atau beberapa jenis antibiotika tertentu (multipledrug resistance) sangat menyulitkan proses pengobatan. Disamping itu, penggunaan antibiotik secara berlebihan menyebabkan bakteri mencoba melakukan berbagai cara untuk melawan antibakteri, sehingga bakteri yang bertahan menjadi lebih kuat dan terus bertambah banyak dan semakin berbahaya (Kurniawan \& Aryana, 2015). Beragam agen yang dapat menginfeksi telah mengembangkan kekebalan, terutama fokus pada resistensi bakteri (Mardiyah, 2018).

Resistennya suatu bakteri terhadap antibiotik diketahui apabila tidak adanya daya hambat yang diberikan pada kadar maksimun yang dapat ditolerir oleh penjamu. Spesies bakteri yang secara normal memberikan respon terhadap antibiotika tertentu mungkin menyebabkan berkembangnya galur resisten (Gaol et al, 2017). Selain karena resistensi, antibiotik, dan juga harga antibiotik yang relative mahal dan juga apabilapenggunaan antibiotik tersebut dalam jangka waktu lama bisa 
memberikan efek samping. Oleh sebab itu pemanfaatan obat-obatan dari tumbuhan semakin sering diteliti salah satunya sebagai antibakteri (Upa et al., 2017).

Perkembangan ilmu pengetahuan dan teknologi pada saat sekarang ini,, tentunya sangat menunjang penggalian penelitian tentang pemanfaatan tanaman sebagai hasil alam dapat dikembangkan sebagai tanaman obat yang mempunyai nilai ekonomi tinggi. Selain harga bahan obat tradisional terbilang lebih murah dan bahan bakunya mudah untuk didapatkan, pemanfaatan bahan alami sebagai obat tradisional dinilai memiliki efek samping yang lebih kecil dibandingkan dengan obat yang berasal dari bahan kimia.

Pengobatan farmakologis telah banyak dikembangkan untuk mengatasi infeksi acne vulgaris akibat mikroorganisme terutama $S$. epidermidis. Namun dengan marak pengobatan alternatif dengan menggunakan bahan-bahan alam, menjadi suatu hal yang patut dikembangkan,salah satunya dengan bawang putih.

Dilihat dari potensinya, bawang putih dapat digunakan sebagai pengganti antibiotik. Karena selain mudah untuk diaplikasikan sebagai obat, bawang putih telah menjadi salah satu tanaman tertua yang dibudidayakan manusia sehingga bawang putih dapat ditemukan di seluruh dunia. Manfaat bawang putih sangat banyak. Bawang putih dipercaya memiliki manfaat antispasme, ekspektoran, antiseptik, bakteriostatik, antiviral, antihelmintik dan antihipertensi (Salim, 2016).

Bawang putih dikenal sebagai antibakteri alami.Zat bioaktif yang berperan sebagai antibakteri dalam bawang putih adalah allisin yang mudah menguap (volatil) dengan kandungan sulfur. Allisin terbentuk dari senyawa organosulfur utama dalam bawang putih yaitu gamma-glutamyl-s-allyl-cysteine dan Sallyl-L-cysteins sulfoxides (alliin) melalui reaksi enzimatis dengan bantuan enzim allinase. Sebagai antibakteri Allisin bekerja dengan mengubah fitur dari protein, lipid dan polysakarida pada selaput sel bakteri (Purwantiningsih et al, 2019).

Derivat sulfur lainnya yang tekandung dalam bawang putih adalah ajoene, alliin, allithiamin, (allithio)sistein, dimetilsulfida, dan dimetil trisulfida. Selain itu kandungan senyawa aktif lainnya yang terkandung di dalam bawang putih adalah minyak atsiri, alkaloid, tanin, saponin, dan flavonoid. Senyawa-senyawa aktif tesebut secara sinergis sebagai antibakteri dengan cara merusak dinding sel dan melisiskan sel bakteri, serta menghambat proteolitik (Soraya et al, 2018).

Sudah dinyatakan bahwa bawang putih, sebagai agen antibakteri, efektif terhadap banyak bakteri gram-positif dan gram-negatif dan efek ini berasal dari allisin. Allisin adalah senyawa sulfur teroksigenasi, yang terbentuk ketika sel bawang putih mengalami kerusakan. Alliin adalah senyawa prekursor dari allisin dan disimpan dalam suatu kompartemen dalam sel bawang putih yang terpisah dari enzimnya yaitu allinase. Ketika sel bawang putih mengalami kerusakan, allin dan allinase akan bercampur dan alliin akan berubah menjadi allicin (Salim, 2016).

Bawang putih(Allium sativum) dapat digunakan dalam tiga bentuk, yaitu ekstrak bawang putih (EBP), minyak bawang putih (MBP), dan tepung bawang putih (TBP). Dari ketiga bentuk umum bawang putih yang sering digunakan, ternyata ada bentuk lain dari bawang putih yang juga dapat dimanfaatkan yaitu bawang putih dalam bentuk larutan atau sering disebut dengan larutan bawang putih (LBP).

Beberapa penelitian sebelumnya menyebutkan bahwa bawang putih mampu menghambat pertumbuhan beberapa bakteri,, baik bakteri Gram positif maupun Gram negatif. Prihandani, (2015) telah melakukan Uji daya antibakteri bawang putih (Allium sativum L.) terhadap tiga bakteri yaitu Staphylococcus aureus, Escherichia coli, Salmonella typhimurium dan Pseudomonas aeruginosa dalam meningkatkan keamanan pangan. Penelitian ini dilakukannya dengan menggunakan metode difusi kertas cakram. Hasil penelitiannya menunjukkan bawang putih pada konsentrasi $50 \%, 25 \%$ dan $12,5 \%$ efektif menghambat pertumbuhan bakteri S.aureus, E.coli, S. typhimurium dan $P$. aeruginosa

Sebelumnya (Salim, 2016) telah melakukan penelitian tentang Pengaruh Ekstrak Bawang Putih (Allium sativum) Terhadap pertumbuhan Bakteri Gram Positif (Staphylococcus aureus) dan Gram Negatif (Escherichia coli) Secara In Vitro. Penelitian ini 
dilakukan dengan metode kirby bauer disk diffusion, hasil penelitiannya menyatakan Bakteri gram-positif ( $S$. aureus) dan gramnegatif (E. coli) tergolong peka terhadap ekstrak bawang putih dengan diameter zona hambat lebih dari $20 \mathrm{~mm}$ dengan kadar $60 \%$, $80 \%$ dan $100 \%$ menurut CLSI edisi ke-11 dengan rerata diameter zona hambat seluruh kelompok konsentrasi 23.78 $\mathrm{mm}$ untuk $S$. aureus dan $22.30 \mathrm{~mm}$ untuk $E$. coli.

Selanjutnya Purwantiningsih et al., (2019) telah melakukan Uji Antibakteri Ekstrak Bawang Putih untuk Menghambat Bakteri Staphylococcus aureus dan Escherichia coli. Uji daya hambat dilakukan dengan metode sumuran. Hasilnya menunjukkan penggunaan larutan ekstrak bawang putih konsentrasi 25\% mampu menghambat bakteri Escherichia coli sebaik larutan antibakteri komersial. Namun, konsentrasi 20\%, 25\%, dan $30 \%$ belum mampu menghambat bakteri Staphylococcus aureus sebaik larutan antibakteri komersial.

Dari beberapa penelitian yang telah dilakukan, belum pernah dilaporkan pengaruh larutan bawang putih terhadap pertumbuhan bakteri yang habitatnya dipermukaan kulit seperti bakteri $S$. epidermis. Oleh karena itu, dilakukan penelitian untuk mengetahui pengaruh larutan bawang putih terhadap pertumbuhan $S$. epidermidis serta untuk mengetahui konsentrasi manakah yang paling efektif dalam menghambat pertumbuhan bakteri $S$. epidermidis.

Penelitian ini bertujuan untuk menguji daya hambat larutan bawang putih dalam menghambat pertumbuhan bakteri $S$. epidermidis serta untuk mengetahui konsentrasi manakah yang paling efektif dalam menghambat pertumbuhan bakteri $S$. epidermidis sehingga dapat menjadi sumber informasi bagi masyarakat mengenai manfaat larutan bawangputih (Allium sativum)dalam menghambat pertumbuhan $S$. epidermidis sehingga dapat menjadi alternatif dalam pengobatan jerawat.

\section{METODE PENELITIAN}

Penelitian eksperimental ini adalah

penelitian laboratorium dengan menggunakan teknik Kirby-Bauer disc diffusion. Tujuan penelitian ini untuk melihat pengaruh larutan bawang putih (Allium sativum ) terhadap pertumbuhan bakteri $S$. epidermidis. Penelitian ini dilaksanakan di
Laborarotium Bakteriologi STIKes Perintis Padang. Sampel yang digunakan adalah bakteri $S$. epidermidis. Penelitian ini menggunakan uji in vitro maka jumlah kelompok sama dengan jumlah pengulangan sesuai rumus Federer. Pada penelitian ini peneliti menggunakan 4 kelompok pada masing-masing konsentrasi $(10 \%, 40 \%, 70 \%$, $100 \%)$. Kontrol positif menggunakan amoxcillin $25 \mathrm{\mu g}$ dan kontrol negatif menggunakan aquadest steril. Alat yang digunakan berupatabung reaksi, jarum Ose, bunsen, mikropipet, pinset, cawan petri, rak tabung, penggaris, kamera, autoclave, alat tulis, label, inkubator, lumpang dan alu, timbangan digital, sarung tangan, masker. Sedangkan bahan yang digunakan berupa larutan bawang putih, media Agar Darah (AD), media Mueller Hinton Agar (MHA), aquadest steril, $\mathrm{NaCl}$, larutan standar $0,5 \mathrm{mF}$, alkohol $70 \%$, biakan bakteri $S$. epidermidis, cakram uji kosong, korek api, swab kapas, tissue, kasa, Amoksilin $25 \mathrm{ug}$, dan aquadest steril.

Alat yang akan digunakan dalam penelitian dicuci bersih lalu disterilisasi dengan menggunakan autoclave selama 15 menit pada suhu $121^{\circ} \mathrm{C}$ dengan tekanan 1,5 atm. Sedangkan untuk bawang putih yang telah dikupas, ditimbang sebanyak $350 \mathrm{~g}$ dengan timbangan digital kemudian bawang dimasukkan kedalam plastik dan ditumbuk hingga halus dengan menggunakan alu dan lumpang. Hasil tumbukan diperas dengan menggunakan kasa yang sebelumnya telah disterilkan. Perasan ditampung pada cawan petri yang telah disterilkan. Selanjutnya, hasil perasan bawang putih dibagi menjadi 4 konsentrasi yaitu 10\%, 40\%, 70\%, 100\%. Sedangkan untuk kultur bakteri, dilakukan dengan menginokulasikan 1 ose biakan murni $S$. epidermidis pada media agar darah lalu diinkubasi pada suhu $37^{\circ} \mathrm{C}$ selama 24 jam didalam inkubator. Selanjutya, bakteri diencerkan dengan mencampurkan 1 ose suspensi $S$. epidermidis kedalam tabung reaksi yang telah berisi $\mathrm{NaCl}$. Selanjutnya dihomogenkan dan kekeruhannya distandarisasikan dengan skala Mc Farland 0,5 . Suspensi lalu dioleskan pada media Mueller Hinton Agar (MHA) dengan menggunakan swab kapas steril. Kontrol positif, kontrol negatif dan cakram uji (direndam 15-30 menit pada masingmasing konsentrasi perasan bawang putih) diletakkan diatas permukaan media Mueller 
Hinton Agar (MHA) secara steril. Selanjutnya diinkubasi ke dalam inkubator selama 24 jam pada suhu $37^{\circ} \mathrm{C}$. Selanjutnya diukur diametar zona hambat (Clear zone) yang terbentuk. Data yang didapat di analis secara deskriptif dan dilihat hubungan masing-masing perlakuan dengan analisa bivariat.

\section{HASIL DAN PEMBAHASAN}

Larutan Bawang putih yang dihasil berwarna kuning kecoklatan. Dari $350 \mathrm{~g}$ bawang putih dihasilkan didapatkan $150 \mathrm{ml}$ larutan bawang putih (Gambar 1).

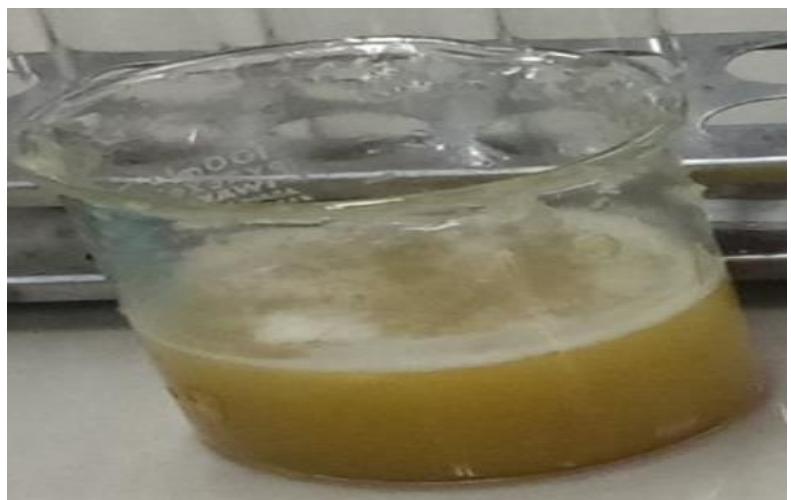

Gambar 1. Larutan Bawang Putih

Dari air larutan bawang putih tersebut dibuat larutan bawang putih dengan variasi konsentrasi 10\%, 40\%, $70 \%$ dan $100 \%$ (Gambar 2.) Tujuan Pembuatan variasi konsentrasi larutan ini untuk menentukan konsentrasi yang paling efektif dalam menghambat pertumbuhan bakteri $S$. epidermidis.

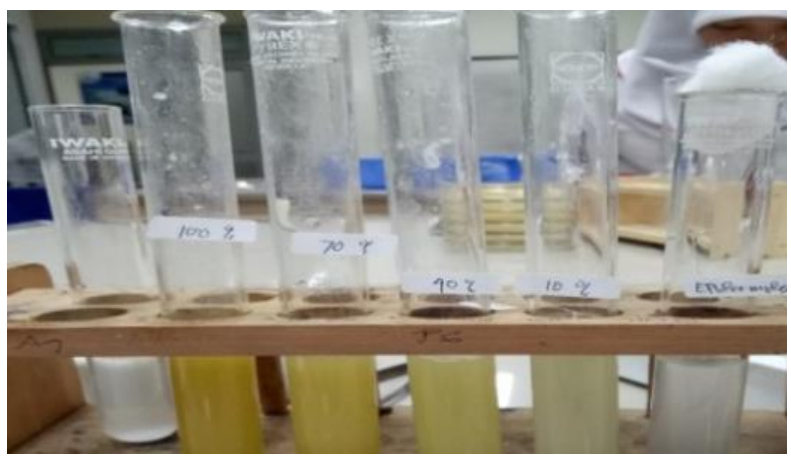

Gambar 2 : Larutan bawang putih dalam berbagai konsentrasi (10\%, 40\%, 70\% dan $100 \%$ )

Pada gambar 2. dapat dilihat perbedaan warna dari masing-masing konsentrasi. Semakin tinggi konsentrasi larutan maka warna yang dihasilkan semakin pekat yaitu dari warna kuning muda pada konsentrasi 10\% hingga warna coklat muda pada konsetrasi $100 \%$. . Pengaruh warna yang mendominasi pada bawang putih ini adalah karena mengandung $0,2 \%$ minyak atsiri yang berwarna kuning kecoklatan. Sampel penelitian yang digunakan merupakan bakteri $S$. epidermidis yang diperoleh dari laboratorium STIKes Perintis Padang. (Gambar 3).

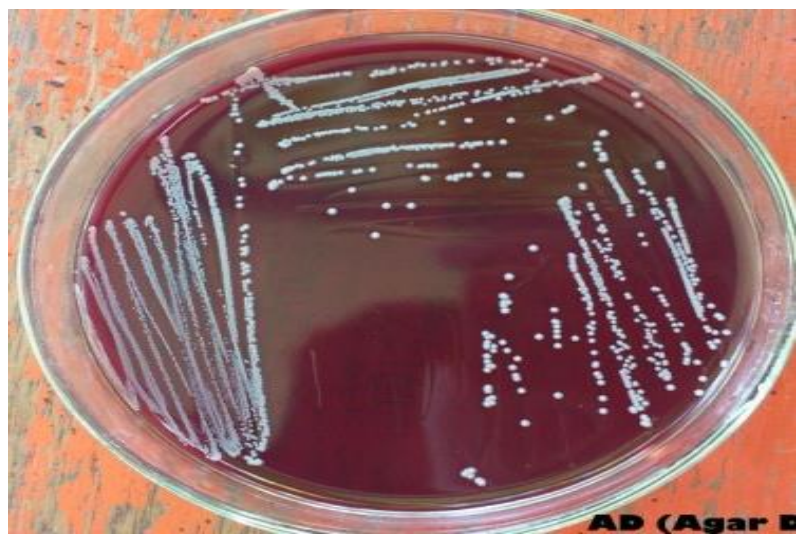

\section{Gambar 3. Koloni Staphylococcus epidermidis pada medium agar darah.}

Pemeriksaan makroskopis dan mikroskopis bakteri uji pada penelitian ini bertujuan untuk mengidentifikasi dari bakteri yang digunakan, yang dilengkapi dengan uji biokimia terhadap bakteri $S$. epidermidis ini. Koloni pada Staphylococcus epidermidis berbentuk bulat, cembung, putih dan unhemolisa (tidak dapat menghemolisis darah). Hasil pewarnaan gramnya adalah gram positif dengan susunan sel bergerombol seperti buah anggur.

Bakteri S. epidermis ini secara alami hidup di membran kulit dan membran mukosa manusia $S$. epidermidis. Bakteri $S$. epidermidis umumnya telah resisten terhadap antibiotik penisilin dan metisilin. Penggunaan metisilin menyebabkan resistensi terhadap antibiotik lain seperti rifamisin, gentamisin, tetrasiklin, kloramfenikol, eritromisin, clindamisin, dan sulfonamide (Mei, 2016).

Hasil identifikasi bakteri uji pada lempeng agar darah setelah inkubasi selama 24 jam pada suhu $37^{\circ} \mathrm{C}$ disajikan pada tabel 1 . Makroskopis dari bakteri $S$. epidermidis, koloni bulat, cembung, berwarna putih sampai dengan abu-abu dan unhemolisa yang menandakan bahwa bakteri S. Epidermidis 
Tabel 1. Identifikasi bakteri Staphylococcus epidermidis pada lempeng Agar Darah, inkubasi $1 \times 24$ jam dengan suhu $37^{\circ} \mathrm{C}$.

\begin{tabular}{|c|c|c|}
\hline No & UJl & HASIL \\
\hline 1. & Pewarnaan Gram & $\begin{array}{c}\text { Coccus gram } \\
\text { positif }(+)\end{array}$ \\
\hline 2. & Susunan sel & $\begin{array}{l}\text { Bergerombol } \\
\text { seperti buah } \\
\text { anggur }\end{array}$ \\
\hline 3. & Morfologi Koloni & $\begin{array}{l}\text { Koloni bulat, } \\
\text { cembung, putih, } \\
\text { unhemolisa }\end{array}$ \\
\hline 4. & Tes Katalase & Positif ( + ) \\
\hline 5. & Tes Mannit & Negatif ( - ) \\
\hline 6. & Koagulase & Negatif ( - ) \\
\hline
\end{tabular}

tidak dapat menghemolisis darah. Mikroskopis dari $S$. epidermidis merupakan bakteri gram positif berbentuk coccus (bulat) yang tersusun bergerombol seperti buah anggur, berdiameter 0,5 - 1,5 $\mu \mathrm{m}$. Tes katalase positif, bakteri $S$. epidermidis menghasilkan gelembung. Gelembung yang dihasilkan pada tes ini adalah Oksigen. Gelembung Oksigen merupakan hasil penguraian $\mathrm{H}_{2} \mathrm{O}_{2}$ (Hidrogen peroksida) diurai menjadi air dan oksigen. Bakteri dengan katalase positif memilki enzim katalase yang mampu menguraikan $\mathrm{H}_{2} \mathrm{O}_{2}$ (Hidrogen peroksida) menjadi air dan oksigen.
Tes Biokimia pada media Mannitol salt bersifat negatif. Mannitol salt merupakan media selektif karena memiliki konsentrasi $\mathrm{NaCl}$ yang tinggi (7,5\%). Bakteri $S$. epidermidis tidak mampu bertahan hidup dilingkungan dengan kadar garam yang tinggi (hipertonik).

Bakteri S. epidermis memiliki karakteristik fisiologis yaitu pada media manitol salt agar yaitu koloninya bulat cembung berwarna putih kekuningan Gram positif, berbentuk bulat, bergerombol, berdiameter 0,5- 1,5 $\mu \mathrm{m}$ dan non motil dan untuk karakteristik biokimia yaitu katalase positif, koagulase negatif dan tidak memfermentasi Manitol (Karimela, 2018).

Metode disk diffusion menggunakan piringan kertas cakram yang berisikan agen antimikroba dan ditanam di atas media agar. Inkubasi dilakukan selama 18-24 jam pada suhu $37^{\circ} \mathrm{C}$. Interpretasi dari uji ini akan terbentuknya daerah bening yang tidak ditumbuhi oleh pembiakan bakteri di media agar yang disebut sebagai zona hambat, jika semakin besar zona hambat yang terbentuk maka semakin efektif agen antimikroba tersebut (Purwantiningsih et al., 2019). Hasil pengamatan uji daya hambat larutan bawang putih terhadap pertumbuhan bakteri $S$. epidermidis dengan metoda disk diffusion dapat dilihat pada tabel 2. Hasil pada tabel 2. menunjukkan larutan bawang putih dapat menghambat pertumbuhan bakteri $S$.

Tabel 2. Hasil PenelitianUji Daya Hambat Bakteri Staphylococcus epidermidis

\begin{tabular}{ccccccc}
\hline $\begin{array}{c}\text { Pengulanga } \\
\mathbf{n}\end{array}$ & $\begin{array}{c}\text { Kontrol } \\
(-)\end{array}$ & $\mathbf{1 0 \%}$ & $\mathbf{4 0} \%$ & $\mathbf{7 0} \%$ & $\mathbf{1 0 0 \%}$ & $\begin{array}{c}\text { Kontrol } \\
(+)\end{array}$ \\
1 & 0 & 11 & 15 & 17 & 19 & 25 \\
2 & 0 & 13 & 17 & 16 & 20 & 25 \\
3 & 0 & 13 & 14 & 18 & 18 & 25 \\
4 & 0 & 11 & 15 & 18 & 19 & 25 \\
5 & 0 & 12 & 15 & 17 & 19 & 25 \\
6 & 0 & 12 & 14 & 16 & 20 & 25 \\
Rata-rata & 0 & 12 & 15 & 17 & 19 & 25 \\
\hline
\end{tabular}

epidermidis. Hal ini dapat dilihat dari zona hambat yang dihasilkan dari berbagai konsentrasi. Larutan bawang putih pada konsentrasi $10 \%, 40 \%, 70 \%$ dan $100 \%$ menghasilkan diameter hambat yang berbeda beda. Semakin tinggi konsentrasi larutan bawang putih yang digunakan, maka semakin besar zona hmabat yang dihasilkan. 
Hasil pengamatan uji daya hambat larutan bawang putih pada konsetrasi 10\%, 40\%, $70 \%$ dan $100 \%$ terhadap pertumbuhan bakteri S. epidermidis yang diikubasi $1 \times 24$ jam pada suhu $37^{\circ} \mathrm{C}$ pada medium MHA dapat dilihat pada gambar 3 .

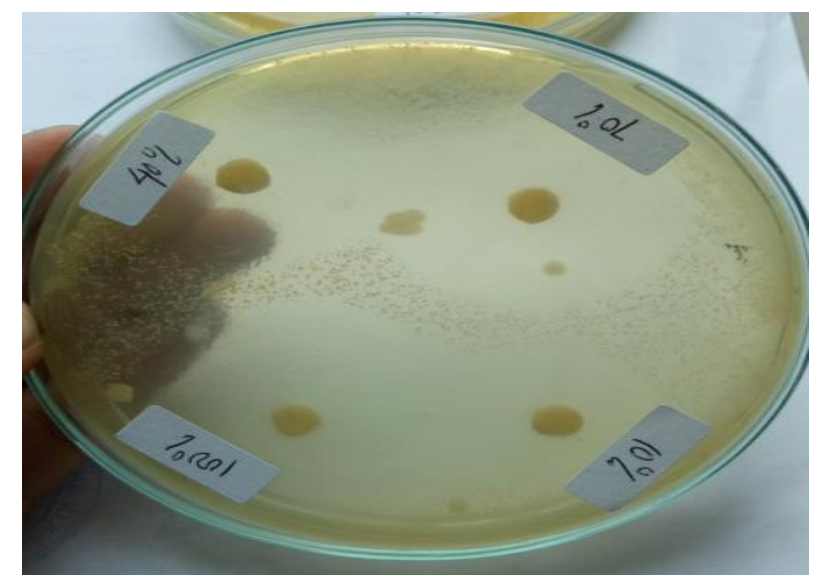

Gambar 3. Hasil uji daya hambat larutan bawang putih terhadap pertumbuhan bakteri Staphylococcus epidermidis yang diikubasi $1 \times 24$ jam pada suhu $37^{\circ} \mathrm{C}$.

$\begin{array}{cc}\text { Metode } & \text { difusi cakram yang prinsipnya } \\ \text { adalah } & \text { menghambat }\end{array}$ mikroorganisme yang diujikan. Zona hambat akan terlihat sebagai daerah jernih di sekitar daerah yang mengandung zat antibakteri. Sensitivitas bakteri terhadap zat antibakteri ditandai dengan terbentuknya diameter zona hambat di sekitar kertas cakram. Zona yang terbentuk pada aktifitas anti bakteri dengan metode disk diffusion menunjukkan adanya pengaruh larutan bawang putih terhadap pertumbuhan bakteri $S$. epidermidis.

Untuk mengetahui pengaruh perlakuan terhadap zona hambat larutan bawang putih terhadap pertumbuhan bakteri $S$. epidermidis dianalisis dengan uji one way anova. Dari hasil analisis dapat diketahui bahwa larutan bawang putih berpengaruh signifikan dalam menghambat pertumbuhan bakteri $S$. epidermidis.

Uji selanjutnya menyatakan bahwa konsentrasi $10 \%$ dan $40 \%$ menunjukkan perbedaan secara signifikan, konsentrasi $40 \%$ dan $70 \%$ juga menunjukkan perbedaan secara signifikan. Dan selanjutnya konsentrasi $70 \%$ dan $100 \%$ juga menunjukkan perbedaan secara signifikan.

Berdasarkan

Pertumbuhan bakteri dapat diklasifikasikan, diameter $>20 \mathrm{~mm}$ menunjukkan respon hambat kuat, diameter 16-20 mm menunjukkan respon hambat sedang, diameter 10-15 $\mathrm{mm}$ menunjukkan respon hambat lemah, dan $<10 \mathrm{~mm}$ menujukkan respon hambat kurang efektif. (Mulyadi, Wuryanti, \& Sarjono, 2017)

Jadi, dari hasil nilai rata-rata diameter hambat dapat diketahui bahwa larutan bawang putih $10 \%$ dan $40 \%$ mempunyai daya hambat lemah terhadap bakteri $S$. epidermidis. Sedangkan konsentrasi $70 \%$ dan $100 \%$ memberikan daya hambat yang sedang terhadap bakteri $S$. epidermidis. Jika dibandingkan dengan kontrol negatif dapat dilihat pada tabel tidak menghasilkan zona hambat. Sedangkan kontrol positif sebagai pembanding ternyata menghasilkan daya hambat yang kuat. terhadap bakteri $S$. epidermidis.

Dari hasil diatas dapat kita simpulkan bahwa konsentrasi yang paling efektif dalam menghambat pertumbuhan bakteri $S$. epidermidis adalah konsentrasi $70 \%$. Karena konsentrasi $10 \%$ dan $40 \%$ daya hambat yang dihasilkan masih tergolong lemah dalam menghambat pertumbuhan bakteri $S$. epidermidis. Sedangkan untuk konsentrasi $70 \%$ dan $100 \%$ sama-sama menunjukkan diameter hambat yang sedang, namun tentu dari kedua konsentrasi ini konsentrasi 70\% dinyatakan lebih efektif dalam menghambat pertumbuhan bakteri $S$. Epidermidis karena konsentrasi larutan bawang putih yang digunakan lebih kecil.

Dari hasil penelitian ini, bisa kita lihat larutan bawang putih dapat digunakan dalam menghambat pertumbuhan $S$. epidermidis sebagai pengobatan seperti jerawat. Pemanfaatan bahan alami ini sebagai obat tradisional lebih dinilai memiliki efek samping yang lebih kecil dibandingkan dengan obat yang berasal dari bahan kimia, disamping itu harga bahan obat tradisional terbilang lebih murah dan bahan bakunya mudah untuk didapatkan.

Uji efektivitas larutan bawang putih Terhadap pertumbuhan bakteri Staphylococcus epidermidis dapat dilihat pada tabel 3. Berdasarkan tabel 3 hasil pengolahan data menunjukkan bahwa konsentrasi $10 \%$ dibandingkan dengan kosentrasi $40 \%, 70 \%$, $100 \%$ terdapat perbedaan bermakna. 
Tabel 3. Uji efektivitas larutan bawang putih Terhadap pertumbuhan bakteri Staphylococcus epidermidis

\begin{tabular}{|c|c|c|c|c|c|c|c|}
\hline \multirow{2}{*}{$\begin{array}{c}(\mathrm{I}) \\
\text { Kosentrasi }\end{array}$} & \multirow{2}{*}{$\begin{array}{c}(\mathrm{J}) \\
\text { Kosentrasi }\end{array}$} & \multirow{2}{*}{$\begin{array}{c}\text { Mean } \\
\text { Difference (I-J) }\end{array}$} & \multirow{2}{*}{$\begin{array}{l}\text { Std. } \\
\text { Error }\end{array}$} & \multirow{2}{*}{ Sig. } & \multicolumn{2}{|c|}{$\begin{array}{l}\text { 95\% Confidence } \\
\text { Interval }\end{array}$} & \multirow[t]{2}{*}{$\begin{array}{c}\text { p } \\
\text { Value }\end{array}$} \\
\hline & & & & & $\begin{array}{l}\text { Upper } \\
\text { Bound }\end{array}$ & $\begin{array}{l}\text { Lower } \\
\text { Bound }\end{array}$ & \\
\hline \multirow[t]{3}{*}{10} & 40 & $-3.000\left(^{*}\right)$ & .530 & .000 & -4.55 & -1.45 & \multirow{12}{*}{0,000} \\
\hline & 70 & $-5.000\left(^{*}\right)$ & .530 & .000 & -6.55 & -3.45 & \\
\hline & 100 & $-7.167\left(^{\star}\right)$ & .530 & .000 & -8.72 & -5.62 & \\
\hline \multirow[t]{3}{*}{40} & 10 & $3.000\left(^{*}\right)$ & .530 & .000 & 1.45 & 4.55 & \\
\hline & 70 & $-2.000\left(^{*}\right)$ & .530 & .007 & -3.55 & -.45 & \\
\hline & 100 & $-4.167\left(^{*}\right)$ & .530 & .000 & -5.72 & -2.62 & \\
\hline \multirow[t]{3}{*}{70} & 10 & $5.000\left(^{\star}\right)$ & .530 & .000 & 3.45 & 6.55 & \\
\hline & 40 & $2.000\left(^{*}\right)$ & .530 & .007 & .45 & 3.55 & \\
\hline & 100 & $-2.167\left(^{*}\right)$ & .530 & .003 & -3.72 & -.62 & \\
\hline \multirow[t]{3}{*}{100} & 10 & $7.167\left(^{*}\right)$ & .530 & .000 & 5.62 & 8.72 & \\
\hline & 40 & $4.167\left(^{*}\right)$ & .530 & .000 & 2.62 & 5.72 & \\
\hline & 70 & $2.167\left(^{*}\right)$ & .530 & .003 & .62 & 3.72 & \\
\hline
\end{tabular}

Konsentrasi $40 \%$ dibandingkan dengan konsentrasi $10 \%$ dan $100 \%$ terdapat perbedaan bermakna sedangkan perbandingaan dengan konsentrasi $70 \%$ tidak terdapat perbedaan bermakna Konsentrasi $70 \%$ dibandingkan dengan konsentrasi $10 \%$ dan $100 \%$ terdapat perbedaan bermakna sedangkan perbandingan dengan konsentrasi $40 \%$ tidak terdapat perbedaan bermakna. Konsentrasi $100 \%$ dibandingkan dengan konsentrasi 10\%, 40\%, 70\% terdapat perbedaan bermakna. Diagram pertumbuhan bakteri pada Media Mueller Hinton dengan 6 kali pengulangan dapat dilihat pada gambar 4 .

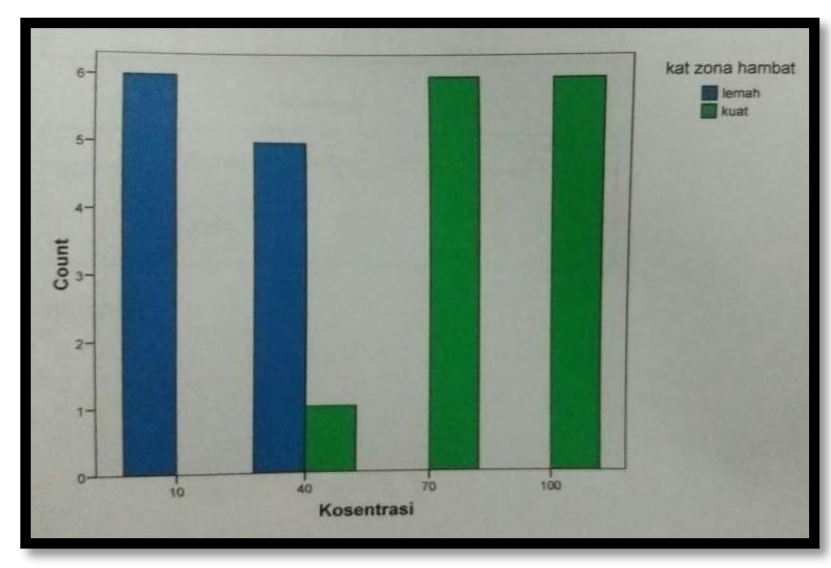

Gambar 4. Signifikasi Pertumbuhan Bakteri
Setelah melakukan penelitian uji efektifitas larutan bawang putih (Allium sativum) terhadap pertumbuhan bakteri $S$. epidermidis maka diperoleh hasil penelitian yang menunjukkan bahwa larutan bawang putih mampu menghasilkan daya hambat terhadap pertumbuhan bakteri $S$. epidermidis. Hal ini dapat dilihat dari terbentuknya daerah bening bebas kuman disekitar cakram yang telah direndam dengan larutan bawang putih dengan berbagai konsentrasi.

Konsentrasi larutan bawang putih yang digunakan sangat mempengaruhi daerah bening yang terbentuk disekitar cakram uji. Pada penelitian ini konsentrasi larutan bawang putih yang digunakan adalah $10 \%, 40 \%, 70 \%$, $100 \%$ dengan kontrol negatif menggunakan aquadest steril dan kontrol positif menggunakan antibiotik amoxycillin. Sensitifitas bakteri terjadi pada larutan bawang putih dengan keempat konsentrasi $10 \%, 40 \%$, $70 \%$ dan $100 \%$.

Berdasarkan penelitian yang telah dilakukan terhadap pengukuran diameter daerah bening pada masing-masing konsentrasi dengan enam kali pengulangan, menunjukkan bahwa larutan bawang putih pada konsentrasi $70 \%$ merupakan konsentrasi yang paling efektif digunakan untuk 
menghambat

Stahpylococcus

pertumbuhan

epidermidis.

bakteri

penggunaan

konsentrasi $\quad 70 \%$

Dengan

telah

menunjukkan daya hambat yang sedang terhadap pertumbuhan $S$. epidermidis. Namun, jika dibandingkan dengan konsentrasi $100 \%$ memang memberikan diameter hambat yang lebih tinggi tapi konsentrasinya terlalu tinggi, namun kategori daya hambat yang diberikan oleh $100 \%$ juga masih tergolong kategori sedang dalam menghambat pertumbuhan $S$. epidermidis.

Adanya daya hambat terhadap pertumbuhan bakteri menunjukkan bahwa terdapat senyawa aktif anti bakteri dalam larutan bawang putih terhadap pertumbuhan bakteri Staphylococcus epidermidis. Semakin tinggi konsentrasi bawang putih, semakin besar diameter daya hambat (DDH) yang dihasilkan, artinya aktivitas antibakteri semakin tinggi (Purwantiningsih et al., 2019).

Hasil penelitian sebelumnya yang telah dilakukan oleh (Mardiyah, 2018) menunjukkan bahwa pada konsentrasi perasan $100 \%, 50 \%$, dan $25 \%$ tidak ditemukan pertumbuhan bakteri Staphylococcus aureus pada media MSA. Berdasarkan hal ini konsentrasi $100 \%, 50 \%$, dan $25 \%$ dikatakan sebagai daya bunuh. Daya bunuh bakteri terjadi pada konsentrasi $25 \%$, $50 \%$, dan $100 \%$ disebabkan karena kandungant zat anti mikroba pada konsentrasi perasan bawang putih tersebut sangat efektif membunuh bakteri Staphylococcus aureus. Semakin tinggi konsentrasi yang digunakan menghasilkan daya bunuh semakin besar.

Selanjutnya Salim (2016) menyimpulkan hasil penelitiannya Bakteri gram-positif ( $S$. aureus) dan gram-negatif (E. coli) tergolong peka terhadap ekstrak bawang putih dengan diameter zona hambat lebihdari $20 \mathrm{~mm}$ dengan kadar $60 \%, 80 \%$ dan $100 \%$. Semakin tinggi konsentrasi yang digunakan maka diameter zona hambat yang dihasilkan juga semakin besar.

Purwantiningsih et al., (2019) melaporkan penggunaan larutan ekstrak bawang putih konsentrasi 25\% mampu menghambat bakteri Escherichia coli sebaik larutan antibakteri komersial. Namun, larutan ekstrak bawang putih konsentrasi $20 \%$, 25\%, dan $30 \%$ belum mampu menghambat bakteri Staphylococcus aureus sebaik larutan antibakteri komersial.

Semakin tinggi konsentrasi maka semakin besar pula jumlah senyawa aktif yang terkandung didalamnya sehingga daya hambat terhadap pertumbuhan kuman semakin besar. Sebaliknya dengan penurunan konsentrasi maka semakin sedikit pula senyawa aktif yang terkandung didalamnya sehingga daya hambat pertumbuhanpun semakin kecil.

Efek antibakteri dari bawang putih disebabkan oleh karena adanya allicin yang merupakan derivat dari kandungan sulfur. Senyawa antibakteri ini yang terdapat pada larutan bawang putih yang bekerja dengan cara merusak dinding sel dan melisiskan sel bakteri. Derivat sulfur lainnya yang tekandung dalam bawang putih adalah ajoene, alliin, allithiamin,sistein, dimetilsulfida, dan dimetil trisulfida. Selain kandungan senyawa aktif lainnya yang terkandung di dalam bawang putih adalah atsiri, alkaloid, tanin, saponin, dan flavonoid. Senyawasenyawa aktif tersebut bekerja secara sinergis sebagai antibakteri dengan cara merusak dinding sel dan melisiskan sel bakteri, serta menghambat proteolitik. Bawang putih dipercaya memiliki manfaat antispasme, ekspektoran, antiseptik, bakteriostatik, antiviral, antihelmintik dan antihipertensi(Salim, 2016).

\section{KESIMPULAN}

Larutan bawang putih dapat menghambat pertumbuhan bakteri Staphylococcus epidermidis pada konsentrasi $10 \%, 40 \%, 70 \%$, $100 \%$, terbukti dengan terbentuknya zona bening disekitar cakram uji. Konsentrasai larutan bawang putih yang paling efektif dalam menghambat pertumbuhan bakteri Staphylococcus epidermidis adalah pada konsentrasi $70 \%$.

\section{REFERENSI}

Afriyanti, R. N. (2015). Akne Vulgaris Pada Remaja. Medical Faculty of Lampung University, 4(6), 102-109.

Gaol, Y. E. L., Erly, E., \& Sy, E. (2017). Pola Resistensi Bakteri Aerob pada Ulkus Diabetik Terhadap Beberapa Antibiotika di Laboratorium Mikrobiologi RSUP Dr. M. Djamil Padang Tahun 2011 - 2013. Jurnal Kesehatan Andalas, 6(1), 164. https://doi.org/10.25077/jka.v6i1.664

Karimela, E. J. (2018). Isolasi Dan Identifikasi Bakteri Staphylococcus Epidermis Pada Isolation and Identification of Staphylococcus Epidermis Bacteria in Pinekuhe Smoked Fish. Jurnal Teknologi 
Perikanan Dan Kelautan, 9(1), 35-42.

Kurniawan, B., \& Aryana, W. F. (2015). Binahong ( Cassia Alata L ) AS inhibitor of Escherichia coli growth. Faculty of Medicine Lampung University, 4(4), 100104.

Mardiyah, S. (2018). Efektivitas Anti Bakteri Perasan Bawang Putih (Allium sativum L.) terhadap Pertumbuhan Staphylococcus aureus. Medicra (Journal of Medical Laboratory Science/ Technology), 1(2), 44-53.

Mei, D. (2016). Pengaruh infusa daun beluntas (Pluchea indica)Terhadap pertumbuhan bakteri Staphylococcus epidermidis. Life Science, 4(1), 60-65.

Meilina, N. E., \& Hasanah, A. N. (2018). Aktivitas Antibakteri Ekstrak Kulit Buah Manggis ((Garnicia mangostana L.) Terhadap bakteri Penyebab Jerawat. Farmaka, 16(2), 322-323.

Mulyadi, M., Wuryanti, W., \& Sarjono, P. R. (2017). Konsentrasi Hambat Minimum (KHM) Kadar Sampel Alang-Alang (Imperata cylindrica) dalam Etanol Melalui Metode Difusi Cakram. Jurnal Kimia Sains Dan Aplikasi, 20(3), 130-135. https://doi.org/10.14710/jksa.20.3.130135

Prihandani, S. S. (2015).Uji daya antibakteri bawang putih (Allium sativum L.) Terhadap bakteri Staphylococcus aureus, Escherichia coli, Salmonella typhimurium Dan Pseudomonas aeruginosa Dalam meningkatkan keamanan pangan Jurnal Informatika Pertanian, 24(1), 53. https://doi.org/10.21082/ip.v24n1.2015.p5 3-58

Purwantiningsih, T. I., Rusae, A., \& Freitas, Z. (2019). Uji In Vitro Antibakteri Ekstrak Bawang Putih sebagai Bahan Alami untuk Menghambat Bakteri Staphylococcus aureus dan Escherichia coli Garlic Extract Antibacterial In Vitro Test as Nature Inggredient to Inhibit Staphylococcus aureus and Escherichia coli. Sains Peternakan, 17(1), 1-4. https://doi.org/10.20961/sainspet.v\%vi\%i. 23940

Salim, H. H. U. (2016). Pengaruh Aktivitas Antimikroba Ekstrak Bawang Putih (Allium sativum) Terhadap Bakteri Gram Positif (Staphylococcus aureus) dan Gram Negatif (Escherichia coli) Secara In Vitro. Fakultas Kedokteran Universitas Lampung, 7, 66-70.

Soraya, C., Chismirina, S., \& Novita, R. (2018). Pengaruh perasan bawang putih (Allium sativum L.) sebagai bahan irigasi saluran akar dalam menghambat Enterococcus faecalis Secara In Vitro. Cakradonya Dental Journal, 10(1), 1-9. https://doi.org/10.24815/cdj.v10i1.10609

Upa, G., Ali, A., \& Purnamasari, Y. (2017). Uji Aktivitas Antibakteri Ekstrak Etanol Bawang Putih ( Allium sativum ) terhadap Pertumbuhan Bakteri Salmonella typhii dan Shigella dysenteriae. Medula, 4(2), 355-360.

Vilar, G. N., Dos Santos, L. A., \& Filho, J. F. S. (2015). Quality of life, self-esteem and psychosocial factors in adolescents with acne vulgaris. Anais Brasileiros de Dermatologia, $\quad$ 90(5), 622-629. https://doi.org/10.1590/abd18064841.201533726

Wahdaningsih, S., Untari, E. K., \& Fauziah, Y. (2014). Antibakteri Fraksi n-Heksana Kulit Hylocereus polyrhizus Terhadap Staphylococcus epidermidis dan Propionibacterium acnes. Pharmaceutical Sciences and Research, 1(3), 180-193. https://doi.org/10.7454/psr.v1i3.3490

Zahrah, H., Mustika, A., \& Debora, K. (2018). Aktivitas Antibakteri dan Perubahan Morfologi Dari Propionibacterium Acnes Setelah Pemberian Ekstrak Curcuma Xanthorrhiza. Jurnal Biosains Pascasarjana, 20(3), 3. https://doi.org/http://dx.doi.org/10.20473 